\title{
Editorial
}

\section{Eight Years of Realizations and Challenges - The Dynamic Process of an Academic Journal Management}

Triple Helix - A Journal of University-Industry-Government Innovation and Entrepreneurship starts its eighth year of publication with several changes underway. We understand that, although the preceding editorial team has well run the journal, it is necessary to evolve permanently. The scholarly publications business has been undergoing unprecedented transformations; movements like open access publishing and preprint publication constantly impose the need to rethink our actions and performance. At the same time, these transformations allow us to seek the best experience for the editorial process and our readers, who are the reason for the journal's existence at the end of the day.

In addition to the new editorial team, the publication strategy is being changed, as already informed in the previous editorial (Cai \& Amaral, 202O). Instead of a single annual issue bringing together the publications approved during the year, the editors decided to publish several issues. For this reason, there will be no more distinction between topical collections and regular issues, valuing all articles equally. However, these changes will not affect Triple Helix publication policy. Once being accepted, the articles will be published advance access and later included in an issue. This change will also allow the elaboration of presentation editorials, which we understand can be a communication channel with the research community and where we intend to discuss a vast array of subjects, ranging from the evolution of the publication itself to conceptual issues of the Triple Helix model.

New changes are being implemented that will be informed in subsequent editorials. It is also important to inform about what will not change. In this 
sense, the editors remain open to proposals of special issues, emphasizing topics relevant to the Triple Helix movement. The quality of manuscripts, the relevance of the research to the Triple Helix community, the ethical process, all remain the same. Currently, two guest editors are collating papers for a special issue on the theme of Triple Helix and sustainability to appear in 2022, based on the sessions and discussions from the last Triple Helix conference organized by the University of São Paulo last June.

An editor's goal for 2021 is to review the whole editorial process, in order to improve it and shorten the delays for the evaluation and publication of articles. To achieve the desired result, it is essential to analyze the journal's statistics, an information that we will share with readers for the first time. The average time of the desk review and the double blind peer-review process is 90-120 days. From the approval of articles to their publication, go more days are necessary, on average. The challenge is to reduce these lead times. Due to the strategy of organizing special issues collated by guest editors, the journal has received 55 manuscripts and approved $40 \%$ of them in the last three years. This strategy remains, although it will be enlarged with an active effort to encourage authors to submit their research results to regular issues. Meanwhile, we will also aim to speed up the review and publication processes.

Between 2014 and June 2021, 81 research articles written by 167 authors have been published, with an average of 2.06 authors per article. Considering that fifteen authors published more than one article, 135 unique authors were counted. Table 1 below shows the fifteen most prolific authors who have published two or more articles during this period. These fifteen authors accounted for $28 \%$ of the authorship.

These 135 authors come from 32 different countries and essentially from universities. Table 2 presents the ten most prolific countries, as informed by the authors. This table should be read as, for example, Brazil has seventeen unique authors from a total of 135 .

Analyzing the authors' affiliation is not so easy due to the double affiliations and changes over time. Table 3 presents the ten most prolific institutions, based on authors' affiliation at the time of publication. In these statistics, we are counting the total authorship. The information in this table should be read as the 167 authorships cover 178 organizations. For example, Chalmers University of Technology was informed as primary affiliation by eight authors.

Another key indicator of an academic journal is the number of citations received by the papers published. According to Google Scholar metrics, the 81 articles published in Triple Helix have received 1,210 citations until August 3oth, 2021. The distribution of these citations ranks the journal with 
TABLE 1 Most prolific authors

Authors Number of Publications

Henry Etzkowitz 6

Annika Steiber $\quad 5$

Sverker Alänge 4

Irina G. Dezhina 4

Christiane Gebhardt $\quad 3$

Yuzhuo Cai 3

Eustache Mêgnigbêto 3

Liudvika Leišytè 3

Josep M. Piqué 3

Tove Brink 3

Guilherme Ary Plonski 2

Jasmina Berbegal-Mirabent 2

Maximilian Fochler $\quad 2$

Annamária Inzelt $\quad 2$

Marcelo Amaral 2

SOURCE: DEVELOPED BY THE AUTHORS

TABLE 2 Ten most prolific countries

Countries Number of Authors

\begin{tabular}{lr}
\hline Brazil & 17 \\
Germany & 14 \\
USA & 13 \\
China & 9 \\
Finland & 8 \\
Norway & 7 \\
Netherlands & 6 \\
Denmark & 6 \\
Austria & 6 \\
Spain & 6 \\
\hline
\end{tabular}

SOURCE: DEVELOPED BY THE AUTHORS 
TABLE 3 Ten most prolific organizations and countries

Institutions Number of Authorships

Chalmers University of Technology $\quad 8$

Federal University of Rio de Janeiro $\quad 7$

International Triple Helix Institute 6

University of Southern Denmark 6

Fluminense Federal University $\quad 6$

Skolkovo Institute of Science $\quad 5$

and Technology

Humboldt-Universität zu Berlin $\quad 5$

São Paulo University $\quad 5$

Delft University of Technology $\quad 5$

Stanford University 4

SOURCE: DEVELOPED BY THE AUTHORS

All Since 2016

$\begin{array}{lrr}\text { Citations } & 1250 & 1180 \\ \text { h-index } & 19 & 18 \\ \text { i1o-index } & 40 & 39\end{array}$

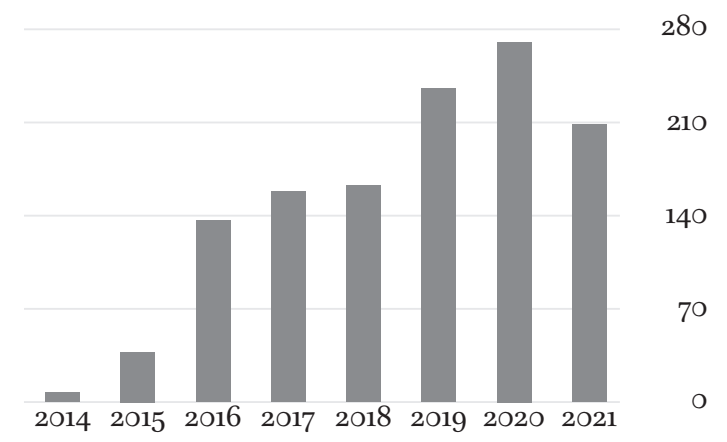

FIGURE 1 Number of citations received per year SOURCE: DEVELOPED BY THE AUTHORS WITH GOOGLE SCHOLAR DATA 
The role of the state in the entrepreneurship ecosystem: insights from Germany G Fuerlinger, U Fandl, T Funke Triple Helix 2 (1), 1-26

$\square$ Smart cities: the state-of-the-art and governance challenge M Deakin

Triple Helix 1 (1), 1-16

$\square$ Implementing the Triple Helix model in a non-Western context: an institutional logics perspective

Y Cai

Triple Helix 1 (1), 1-20

Relational capital for shared vision in innovation ecosystems

MG Russell, J Huhtamäki, K Still, N Rubens, RC Basole

Triple Helix 2 (1), 1-36

Making a humanities town: knowledge-infused clusters, civic entrepreneurship and civil society in local innovation systems

H Etzkowitz

Triple Helix 2 (1), 1-22

$\square$ Can synergy in Triple Helix relations be quantified? A review of the development of the

Triple Helix indicator

L Leydesdorf, HW Park

Triple Helix 1 (1), 1-18

$\square$ Organizational innovation: verifying a comprehensive model for catalyzing organizational development and change

A Steiber, S Alänge

Triple Helix 2 (1), 1-28

$\square$ University-business-government collaboration: from institutes to platforms and ecosystems

GS Nyman

Triple helix 2 (1), 1-20

$\square$ Gendered innovations: harnessing the creative power of sex and gender analysis to discover new ideas and develop new technologies

L Schiebinger

Triple Helix 1 (1), 1-17

Triple Helix and the evolution of ecosystems of innovation: the case of Silicon Valley JM Pique, J Berbegal-Mirabent, $\mathrm{H}$ Etzkowitz

Triple Helix 5 (1), 1-21

FIGURE 2 Ten most cited papers

SOURCE: DEVELOPED BY THE AUTHORS WITH GOOGLE SCHOLAR DATA

an H-index of 19 and an i1o-index of 36. In our modest opinion, these are good ratings for a journal oriented to a specific audience. Figures 1 and 2 present the number of citations received by year and the ten most cited papers.

To conclude this editorial, we'd like to invite the readers to contribute to the journal and interact with the Triple Helix Association (THA). A number of initiatives are to be launched by the тнA for further developing the Triple Helix research community that will be announced in the THA Newsletter. To the Triple Helix audience, enjoy the content of this issue and keep aware of the coming news.

\author{
Marcelo Amaral and Yuzhuo Cai \\ Co-Editors-in-Chief of Triple Helix \\ September 2021
}




\section{References}

Cai, Y., \& Amaral, M. (2020). Milestones of Triple Helix in a year of hardships. Triple Helix, 7(2-3), 123-127. doi:10.1163/21971927-12340002. 